ROBERT SROKA

\author{
$\stackrel{\circ}{\|}$

\section{SAMOREGULACJA BIZNESOWA \\ W ZAKRESIE ETYKI BIZNESU FIRM ZACHODNICH JAKO ODPOWIEDŹ NA ŁAMANIE PRAW PRACOWNICZYCH W CHINACH}

\begin{abstract}
Robert Sroka. Samoregulacja biznesowa w zakresie etyki biznesu firm zachodnich jako odpowiedź na łamanie praw pracowniczych w Chinach [Business self-regulation in terms of business ethics of Western companies as a response to violation of employee rights in China] edited by W. Banach, M.A. Michalski, J. Sójka „" Człowiek i Społeczeństwo" vol. XLVI: Między Chinami a Zachodem. Pytanie oźródła chińskiego sukcesu gospodarczego [Between China and the West. An inquiry into the sources of the Chinese economic miracle], Poznań 2018, pp. 145-158, Adam Mickiewicz University. Faculty of Social Sciences Press. ISSN 0239-3271.
\end{abstract}

Salary that does not meet basic life needs, working conditions that threaten life and health, employing children, forced labor, lack of freedom of association, long hours of work, destroying the environment, widespread corruption is just the beginning of a long list of unethical behaviors of companies in China, as well as Western companies producing in China.

Under the pressure of non-governmental organizations and consumer boycotts in Europe and the USA, business self-regulatory initiatives have been created to raise working conditions at Chinese suppliers. The most popular self-regulations initiatives in terms of business ethics are: Ethical Trade Initiative (ETI), Business Social Compliance Initiative (amforiBSCl), Social Accountability 8000 (SA8000), International Council of Toy Industries (ICTI). Conducting research on self-regulation in the field of business ethics of Western companies operating in China, I analyze three issues. The first is to describe the source of the need to apply such self-regulatory initiatives, which is the outsourcing business strategy. The second element is to define the minimum rules that are broken due to the use of an outsourcing strategy. The third point of consideration is the presentation of the self-regulatory initiatives.

Robert Sroka, Akademia Leona Koźmińskiego, Katedra Przedsiębiorczości i Etyki w Biznesie, ul. Jagiellońska 57/59, 03-301 Warszawa, e-mail: rsroka@kozminski.edu.pl 


\section{Wprowadzenie}

Wynagrodzenie niepozwalające na zaspokojenie podstawowych potrzeb życiowych, warunki pracy zagrażające życiu i zdrowiu, zatrudnianie dzieci, praca przymusowa, brak wolności zrzeszania się, długie godziny pracy, zatruwanie środowiska, powszechna korupcja - to tylko początek długiej listy zarzutów, jakie od wielu lat stawiane są przez organizacje pozarządowe przedsiębiorcom w Chinach, a także firmom zachodnim przenoszącym produkcję do Państwa Środka lub kupującym tam na wielką skalę produkty i usługi.

Źródłem masowej produkcji w Chinach dla firm z Europy i Stanów Zjednoczonych jest biznesowa strategia outsourcing. Celem tej strategii jest obniżenie kosztów produkcji poprzez przeniesienie jej do krajów, w których zarówno koszty pracy są niższe, jak i formalne obciążenia - związane, chociażby z brakiem wygórowanych obostrzeń w zakresie ochrony środowiska czy bezpieczeństwa i higieny pracy, - nie generują dodatkowych kosztów dla przedsiębiorcy. Przeniesienie produkcji do takich krajów jak Chiny to również mniejsze koszty w zakresie zarządzania. Ale to także uwolnienie się od odpowiedzialności przez zachodnie firmy za przestrzeganie standardów pracy, dbałości o ochronę środowiska, niwelowanie negatywnego oddziaływania na otoczenie zewnętrzne czy stosowanie się do przepisów dotyczących prowadzenia prac badawczo-rozwojowych.

Brak skutecznych chińskich prawnych regulacji na poziomie krajowym w latach dziewięćdziesiątych XX stulecia i na początku XXI w. zapewniających przestrzeganie podstawowych praw człowieka spowodował, że pod naciskiem zachodnich organizacji pozarządowych i bojkotów konsumenckich w Europie i Stanach Zjednoczonych powstały inicjatywy samoregulacyjne mające na celu poprawienie m.in. warunków pracy u chińskich dostawców. Przedsięwzięcia samoregulacyjne, jak Ethical Trading Initiative (ETI), Business Social Compliance Initiative (amforiBSCI), Social Accountability 8000 (SA8000), 10 Zasad Global Compact ONZ, Wytyczne OECD dla przedsiębiorstw wielonarodowych, International Council of Toy Industries (ICTI), zrzeszają przedsiębiorców, którzy zobowiązują się do przestrzegania minimalnych standardów etycznych określonych przez te inicjatywy oraz do zapewnienia, że takie minimalne standardy będą przestrzegane także u ich dostawców, również z Chin, niezależnie od wymagań prawnych i praktyk biznesowych tam obowiązujących. Niniejszy artykuł podejmuje problematykę inicjatyw samoregulacyjnych powoływanych przez firmy, organizacje 
branżowe lub niezależne organizacje pozarządowe w zakresie poprawy standardów pracy w fabrykach ulokowanych w Azji, które znajdują się w łańcuchu dostaw firm zachodnich. Warto zatem dokonać krytycznej oceny skuteczności tych licznych przedsięwzięć samoregulacyjnych.

Prowadząc badania nad samoregulacją,oparte na analizie literatury w zakresie etyki biznesu firm zachodnich stosowanej w Chinach, należy rozważyć trzy zagadnienia. Pierwszym są źródła konieczności stosowania tego typu inicjatyw samoregulacyjnych, jak strategia biznesowa outsourcingu. Innymi słowy, niezbędne jest zbadanie rzeczywistej sytuacji biznesowej, będącej przyczyną problemów etycznych. Drugi element to ustalenie zasad minimalnych, które są łamane na skutek stosowania strategii outsourcingu. Trzeci punkt rozważań stanowi przedstawienie prób odpowiedzi na sytuację problemową na gruncie etyki biznesu. Taką zaś odpowiedzią są inicjatywy samoregulacyjne. Na koniec warto się zastanowić, czy samoregulacja jako odpowiedź biznesu na łamanie podstawowych standardów etycznych jest wystarczająca.

\section{Outsourcing}

Pisząc o inicjatywach samoregulacyjnych w zakresie określania biznesowych standardów etycznych w Chinach przez firmy z Zachodu, należy zacząć od przedstawienia krótkiego rysu outsourcingu jako strategii biznesowej, która stanowi źródło łamania podstawowych praw człowieka i praw pracowniczych.

Nazwa outsourcing jest akronimem wyrażenia outside resource using, co oznacza korzystanie z zasobów zewnętrznych. Termin ten został po raz pierwszy użyty w 1979 r. w odniesieniu do procederu kupowania niemieckich projektów przez brytyjski przemysł motoryzacyjny. Radosław Malik za początek przenoszenia produkcji własnej firmy za granicę uznaje już wiek XVII, czyli czas merkantylizmu oraz kolonialnego imperializmu. Właśnie wtedy po raz pierwszy ówczesne mocarstwa decydowały się na przesunięcie części swojej produkcji do zagranicznych, najczęściej zamorskich lokalizacji. Jako przykład można podać tutaj Kompanię Wschodnioindyjską zakładającą swoje faktorie w Indiach ${ }^{1}$.

Współcześnie outsourcing zaczął się dynamicznie rozwijać w latach osiemdziesiątych XX w. pod wpływem chęci zmniejszenia kosztów produkcji.

\footnotetext{
${ }^{1}$ R. Malik, Lokalizacja w offshoringu usług, CeDeWu Warszawa 2016, s. 52.
} 
Należy zauważyć, że był on możliwy przede wszystkim dzięki rozwojowi szybkiego transportu i technik komunikacji. W początkowym okresie oznaczał przede wszystkim zamawianie przez przedsiębiorstwo półproduktów i podzespołów za granicą. Natomiast w latach dziewięćdziesiątych w ten sposób nazywano wykonywanie określonych usług lub produktów w przedsiębiorstwach położonych w innych krajach². Ten trend zamawiania nie tylko prostych półproduktów, lecz również zaawansowanych usług technologicznych utrzymuje się nadal.

Definiując outsourcing, można wskazać za Michałem Trockim, że jest on metodą zarządzania, która sprowadza się do zawężenia zakresu zadań realizowanych bezpośrednio przez dane przedsiębiorstwo i powierzenia ich do stałej realizacji przez inne podmioty gospodarcze $e^{3}$. Idea outsourcingu zakłada, że dla prawie każdej funkcji, obszaru, procesu, które mogłyby być realizowane w ramach klasycznej struktury organizacyjnej przedsiębiorstwa, można znaleźć alternatywę w postaci usług oferowanych przez zewnętrznych, wyspecjalizowanych dostawców. Z tego powodu outsourcing określany jest jako metoda stałej obsługi zewnętrznej przez wyspecjalizowane podmioty.

Natomiast Marek Matejun definiuje outsourcing jako metodę organizacji i zarządzania polegającą na względnie trwałym, długoterminowym, opartym na kontrakcie przeniesieniu odpowiedzialności za realizację określonych obszarów działalności gospodarczej (zadań, funkcji lub procesów) na stronę wyspecjalizowanego partnera zewnętrznego, przy uwzględnieniu dynamicznego, interakcyjnego i partnerskiego charakteru współpracy nakierowanej na uzyskanie korzyści ekonomicznych i jakościowych oraz przy jednoczesnej możliwości rozwijania kluczowych kompetencji przedsiębiorstwa zlecającego, co umożliwia wzmocnienie jego kluczowej działalności, budowanie przewagi konkurencyjnej i rozwój firmy ${ }^{4}$. W tej definicji został podkreślony fakt przeniesienia odpowiedzialności, a de facto formalnego uwolnienia się od odpowiedzialności za realizację i skutki realizacji zleconych zadań biznesowych.

Ze względu na historię imperium brytyjskiego początkowo główną lokalizacją dla przenoszonych działalności usługowych były Indie. Zmiany

${ }^{2}$ W. Budner, Tendencje rozwoju rynku nowoczesnych usług biznesowych w Polsce, „Acta Sci. Polonorum. Administratio Locorum” 16(1)/2017, s. 20.

${ }^{3}$ M. Trocki, Outsourcing, PWE, Warszawa 2001, s. 13.

${ }^{4}$ M. Matejun, Outsourcing, w: K. Szymańska (red.), Kompendium metod i technik zarzq̨dzania. Teoria i ćwiczenia, Oficyna a Wolters Kluwer business, Warszawa 2015, s. 212. 
uwarunkowań geopolitycznych i ekonomicznych spowodowały, że zainteresowanie zachodnich firm skierowało się także na trzy inne regiony świata: Azję Południowo-Wschodnią (czyli takie kraje, jak Chiny, Wietnam, Filipiny, Malezja czy Indonezja), Amerykę Łacińską oraz kraje Europy Środkowo-Wschodniej ${ }^{5}$.

W kontekście outsourcingu Chiny są nazywane fabryką świata, Indie natomiast określane jako zaplecze biurowe ${ }^{6}$. W niniejszym tekście uwaga będzie skierowana na zagadnienie samoregulacji w kontekście outsourcingu produkcji, a więc na problemie, który dotyczy głównie takich krajów jak Chiny. Robyn Meredith podkreśla, że inwestorzy wybierają rozwijające się Chiny jako miejsce lokalizacji swoich fabryk lub outsourcingu ze względu na korzyści wynikające z niskich kosztów pracy wielomilionowej siły roboczej, dość rozwiniętą infrastrukturę i technologię sprzyjającą eksportowi oraz ogromny wewnętrzny rynek zbytu. Autorka stwierdza, że dzięki tym elementom Chiny wyprzedziły Indie oraz inne kraje rozwijające się, gdyż żaden z nich nie jest w stanie zaproponować potencjalnym inwestorom tak korzystnego zestawu czynników ${ }^{7}$. Firma konsultingowa A.T. Kearney, która co roku publikuje ranking dwudziestu krajów najchętniej wybieranych jako lokalizację procesów outsourcingowych, w czołówce tego zestawienia od kilku lat niezmiennie umieszcza właśnie Chiny ${ }^{8}$.

Dostępne dane z roku 2016 wskazują, że chińskie firmy podpisały kontrakty na usługi outsourcingowe o wartości 130,9 mld USD, co stanowi wzrost o $22,1 \%$ w stosunku do roku poprzedniego. Kontrakty z firmami ze Stanów Zjednoczonych i Unii Europejskiej, które są dwoma głównymi partnerami handlowymi Chin, wzrosły odpowiednio o 17,5 i 17,6\%9.

Outsourcing w niektórych branżach rozwinął się do tego stopnia, że praktycznie cała ich produkcja została przeniesiona do krajów azjatyckich. Przykładowo, większość firm z sektora odzieżowego, obuwniczego, zabawkowego czy elektronicznego przekształciła swoją działalność, skupiając się wyłącznie na projektowaniu i sprzedaży kolekcji, całość produkcji zlecając dostawcom dysponującym tańszą siłą roboczą.

5 W. Budner, op. cit., s. 20.

${ }^{6}$ R. Meredith, Chiny i Indie - supermocarstwa XXI wieku, Media Lazar, Warszawa 2009, s. 132.

7 Ibidem, s. 106.

82016 A.T. Kearney Global Services Location Index TM Top 20, www.atkearney.com/ strategic-it/global-services-location-index, dostęp 15.10.2018.

9 China's service outsourcing grows in 2015, http://www.chinadaily.com.cn/business/ chinadata/2016-01/20/content_23167866.htm, dostęp: 9.11.2018. 


\section{Problemy etyki biznesu związane z procesem outsourcingu w Chinach}

Warunkiem outsourcingu jest porozumienie umożliwiające m.in. przeniesienie odpowiedzialności za wykonywanie usług na firmę zewnętrzną oraz podział korzyści i ryzyka pomiędzy partnerów. Pomijając elementy czysto biznesowe wynikające z rozkładu korzyści na rzecz firm zachodnich i ryzyka na niekorzyść firm z Chin, zwróćmy uwagę na konsekwencje społeczne outsourcingu. Zalicza się do nich, wspomniane już: wynagrodzenie niepozwalające na zaspokojenie podstawowych potrzeb życiowych, warunki pracy zagrażające życiu i zdrowiu, zatrudnianie dzieci, pracę przymusową, brak wolności zrzeszania się, długie godziny pracy, zatruwanie środowiska, powszechną korupcję. Jest to tylko początek długiej listy zarzutów, jakie od wielu lat stawiane są przez organizacje pozarządowe przedsiębiorcom w Chinach, a także firmom zachodnim przenoszącym produkcję do Państwa Środka.

W 2014 r. organizacja non-profit China Labor Watch, której celem jest zwiększenie przejrzystość łańcuchów dostaw i warunków pracy w chińskich fabrykach, opublikowała raport mówiący o ciągłych naruszeniach praw pracowniczych w przemyśle zabawkarskim. Raport jest wynikiem śledztwa przeprowadzonego w kilku chińskich fabrykach zabawek i wskazuje na dwadzieścia przykładów łamania praw pracowniczych. Zaliczono do nich dyskryminację przy zatrudnianiu, konfiskowanie dowodów osobistych pracowników, brak badań lekarskich wymaganych przy pracy w niebezpiecznych warunkach, wymuszanie na pracownikach podpisywania formularzy z odbytych szkoleń mimo braku takich szkoleń, brak odzieży ochronnej, brak napraw i konserwacji maszyn, niejasne procedury przeciwpożarowe, niekompletne umowy o pracę lub ich brak, nawet 120 nadgodzin w miesiącu, niewypłacanie wynagrodzeń, niskie ubezpieczenia społeczne, częste rotacje pracowników na dziennych i nocnych zmianach, złe warunki mieszkaniowe, zanieczyszczenie środowiska, bezprawne procedury zwalniania pracowników, nadużycia władzy, fałszerstwa finansowe, brak odpowiednich procedur umożliwiających pracownikom wnoszenie skarg oraz brak możliwości dochodzenia swoich praw dzięki związkom zawodowym ${ }^{10}$. Sytuacja na przestrzeni kilkunastu ostatnich lat niewiele się zmienia. Podobne

${ }^{10}$ M. Krukowska, Nieludzkie oblicze zabawek, „Forbes” 2.12.2014, https:// www.forbes. pl/csr/lamanie-praw-czlowieka-przez-przemysl-zabawkarski/fct40s8, dostęp: 12.11.2018. 
wyniki nadużyć w zakresie praw pracowniczym pokazywane są od końca lat dziewięćdziesiątych ubiegłego wieku.

Podobne problemy występują nadal. China Labor Watch przeprowadziła inne śledztwo, którego wyniki przedstawiła w raporcie z 2018 r. zatytułowanym An Investigative Report on HEG Technology: A Samsung and Xiaomi Supplier Factory. Opisuje w nim następujące udowodnione naruszenia praw pracowników w firmach produkujących elektronikę: dyskryminujące praktyki zatrudniania (osoby w wieku powyżej 39 lat nie są zatrudniane); niewystarczające szkolenie przed rozpoczęciem pracy, krótsze niż przewidziane przepisami prawa 24 godziny; brak udzielania pracownikom kopii ich umowy o pracę; fałszywe informacje o wysokości wynagrodzenia podawane w materiałach reklamowych; obniżanie premii za obecność przy braku zgody na pracę w nadgodzinach; brak odpowiedniego bezpieczeństwa pożarowego ${ }^{11}$.

Wyników z podobnych raportów prezentujących łamanie praw człowieka i praw pracowniczych w Chinach można przytaczać setki. Każdy z nich wyraźnie wskazuje na istnienie problemu łamania praw pracowniczych, brak dbałości o ochronę środowiska naturalnego oraz problemy związane z fałszerstwami finansowymi i korupcją. W większości tych raportów jako współwinnych wskazuje się korporacje, głównie zachodnie, które przyczyniają się do takiej sytuacji. Zarzuca się im brak zainteresowania przestrzeganiem praw pracowników w chińskich zakładach, które niejednokrotnie produkują na potrzeby tylko jednego lub kilku odbiorców z Europy czy Stanów Zjednoczonych. Nie można zapominać, że taka sytuacja jest wypadkową wielu czynników: oprócz ekonomicznych nacisków firm zachodnich również elementów kulturowych czy polityki państwa.

\section{Samoregulacja biznesowa}

Niektóre organizacje pozarządowe w celu poprawy warunków pracy w Chinach, oprócz przygotowywania raportów, prowadzą też akcje bojkotu konsumenckiego, inne starają się współpracować z biznesem w ramach inicjatyw samoregulacyjnych.

Pisząc o samoregulacji, rozpocznijmy od krótkiej definicji tego zjawiska. Przemysław Hensel definiuje samoregulację biznesu jako tworzenie przez stowarzyszenia biznesowe regulacji, wskazówek i dobrych praktyk

${ }^{11}$ An Investigative Report on HEG Technology: A Samsung and Xiaomi Supplier Factory, China Labor Watch, New York 2018. 
w dziedzinie danej gospodarki/sektora/grupy przedsiębiorstw. Powstałe w ten sposób regulacje nie mają mocy prawnej, ich skuteczność wynika zaś z kontroli poczynań przedsiębiorstw przez inne przedsiębiorstwa działające $\mathrm{w}$ tej samej branży ${ }^{12}$. Ta definicja powinna zostać uzupełniona o stwierdzenie, że kontrole prowadzone są najczęściej przez organizacje branżowe lub niezależne podmioty powołane przez te organizacje. Anna Mokrysz-Olszyńska podkreśla, że obecnie wszystkie główne międzynarodowe organizacje gospodarcze podejmują aktywność w zakresie promowania samoregulacji. Samoregulacja określana jest powszechnie angielskim terminem self-regulatory-system (SRO) i traktowana jako ważny rodzaj tzw. prawa miękkiego (soft law) ${ }^{13}$, czyli takiego, które co do zasady nie ma mocy prawnej, jednak ma praktyczne znaczenie dla jego adresató ${ }^{14}$. Przywołana autorka definiuje samoregulację jako „wszelkie formy regulacji, które nie są wprowadzane w drodze ustawowo określonej procedury stanowienia prawa i nie są egzekwowane w drodze postępowania przed sądami państwowymi. W systemie tym zasady określające postępowanie na rynku są ustalane, monitorowane i egzekwowane przez członków społeczności (lub ich bezpośrednich reprezentantów), której postępowanie jest przedmiotem regulacji”"

Próby wypracowania jakościowo dobrej i wiarygodnej samoregulacji przez samych Chińczyków lub chociażby zastosowania międzynarodowej samoregulacji bez zewnętrznego nadzoru nie powiodły się do tej pory. Wystarczy podać przykład zastosowania samoregulacji, jaką jest standard ISO 9001 dotyczący jakości produkcji, który może stanowić podstawę do przestrzegania praw pracowniczych dzięki zdefiniowanym wymogom jakościowym. Zdaniem Godfreya Yeung i Vincenta Moka wiele chińskich firm z certyfikatem ISO nie spełnia wymagań określonych przez te normy pomimo przejścia audytu niezależnej strony trzeciej i uzyskania certyfikatu ${ }^{16}$.

12 P. Hensel, Ponadnarodowi normodawcy i biznes, w: B. Glinka, M. Kostera (red.), Nowe kierunki w organizacji i zarzqdzaniu. Organizacje, konteksty, procesy zarzq̨dzania, Oficyna a Wolters Kluwer business, Warszawa 2012, ss. 47-48.

13 A. Mokrysz-Olszyńska, Rola kodeksów dobrych praktyk w ochronie konsumenta, w: C. Banasiński (red.), Ochrona konkurencji i konsumentów w Polsce i Unii Europejskiej (studia prawno-ekonomiczne), Urząd Ochrony Konkurencji i Konsumentów, Warszawa 2005, s. 267.

${ }^{14}$ L. Senden, Soft Law in European Community Law, Hart Publishing, Oxford-Portland 2004, s. 111.

15 A. Mokrysz-Olszyńska, op. cit., s. 267.

${ }^{16}$ G. Yeung, V. Mok, What are the Impacts of Implementing ISOs on the Competitiveness of Manufacturing Industry in China?, „Journal of World Business” 40(2)/2005, ss. 142-144. 
Nie inaczej jest, gdy mowa o samoregulacji w zakresie dbałości o środowisko naturalne ${ }^{17}$ czy samoregulacji sektorowych, m.in. w branży internetowej ${ }^{18}$. Badania prowadzone przykładowo przez Petrę Christmann i Glena Taylora udowodniły, że jakość samoregulacji w zakresie przestrzegania praw pracowników czy standardów środowiskowych zależy od preferencji i zaangażowania klientów w tym zakresie, czyli w kontekście naszych rozważań - od zachodnich korporacji ${ }^{19}$.

Dlatego kilka organizacji pozarządowych przy współpracy największych firm z poszczególnych branż powołało inicjatywy samoregulacyjne w zakresie etyki biznesu, które obejmują również, a może przede wszystkim, producentów zlokalizowanych w Chinach. Zaliczają się do tych inicjatyw m.in.: Ethical Trade Initiative (ETI), Business Social Compliance Initiative (amforiBSCI), Social Accountability 8000 (SA8000), International Council of Toy Industries (ICTI).

\section{Podstawy i obszar samoregulacji w zakresie etyki biznesu}

Fundamentem wszystkich powyżej wspomnianych inicjatyw samoregulacyjnych są prawa człowieka. Odwołanie do Powszechnej Deklaracji Praw Człowieka oraz konwencji Międzynarodowej Organizacji Pracy jako podstaw jest wyrażone wprost w każdym znaczącym kodeksie stanowiącym międzynarodową samoregulację w zakresie etyki biznesu. Przyjrzyjmy się obszarom, jakie w ramach poszczególnych inicjatyw samoregulacyjnych zostały unormowane i czy odpowiadają one na wyżej wskazane problemy zamieszczone w raportach z śledztw dotyczących łamania praw pracowników w Chinach.

Ethical Trade Initiative Base Code to kodeks postępowania wypracowany przez organizację ETI. Wymagania zawarte w tym dokumencie dotyczą przede wszystkim obszaru miejsca pracy, w tym warunków zatrudniania, wolności zrzeszania się, standardów bezpieczeństwa i higieny pracy, wysokości wynagradzania, przestrzegania godzin pracy, równego traktowania

17 P. Christmann, G. Taylor, Globalization and the Environment: Determinants of Firm Self-Regulation in China, ,Journal of International Business Studies 32/2001, ss. 439-458.

18 L. Cao, A Study on Self-Regulatory Initiatives in China's Internet industry, Media@ lse, London School of Economic and Political Science, London 2007, ss. 2-59.

19 P. Christmann, G. Taylor, Firm Self-Regulation Through International Certifiable Standards: Determinations, of Symbolic Versus Substantive Implementation, Paper submitted to the First Annual Conference on Institutional Mechanisms for Industry Self-Regulation Dartmouth University, Hanover, NH 2014, s. 34. 
oraz przestrzegania praw człowieka, takich jak niekorzystanie z pracy przymusowej czy z pracy dzieci. Aby umożliwić zachodnim firmom skuteczne użycie kodeksu i sprawdzenie, czy rzeczywiście ich dostawcy, także z Chin, przestrzegają określonych w nim standardów, została opracowana procedura audytowa SMETA (Sedex Members Ethical Trade Audit). Audyt prowadzony na bazie tej procedury odnosi się do czterech obszarów: standardów pracy, bezpieczeństwa i higieny pracy, etyki biznesu oraz dbałości o środowisko. Audyty mogą przeprowadzać tylko jednostki posiadające odpowiednie uprawnienia. Wyniki audytu SMETA mogą być zamieszczane w formie raportu na platformie organizacji SEDEX (Supplier Ethical Data Exchange). Raport może być widoczny nie tylko dla firmy, która zleciła dane badanie, lecz również dla innych członków tej inicjatywy samoregulacyjnej. O popularności audytów SMETA świadczy fakt, że na świecie do roku 2018 przeprowadzono ich już ponad 280 000, a na platformie SEDEX znajduje się ponad 93000 raportów SMETA. Kontrahenci, do których należą największe międzynarodowe podmioty, mogą się z nich dowiedzieć, w jakim stopniu ich obecni lub potencjalni dostawcy spełniają standardy etyczne, społeczne i środowiskowe ${ }^{20}$. Znaczna część audytów została przeprowadzona w Chinach, jednak nie są dostępne szczegółowe informacje o liczbie i podziale geograficznym.

Inną popularną inicjatywą samoregulacyjną jest amforiBSCI. Stanowi on jeden ze standardów audytowych stworzonych przez organizację amfori. BSCI powstało jako inicjatywa zrzeszająca ponad 2000 firm, głównie z Europy, których obroty przekraczają bilion euro, a które wymagają od swoich dostawców spełniania wymagań zawartych w kodeksie postępowania - amfori BSCI Code of Conduct. Określa on wartości i zasady, którymi uczestnicy inicjatywy amforiBSCI powinni się kierować w społecznie odpowiedzialnym zarządzaniu łańcuchem dostaw. W zakresie audytu na zgodność ze standardem amforiBSCI weryfikowane są następujące obszary: systemy zarządzania odpowiedzialnością społeczną oraz efekt kaskadowy (w łańcuchu dostaw), zaangażowanie i ochrona pracowników, wolność zrzeszania, brak dyskryminacji, godziwe wynagrodzenie, odpowiednie godziny pracy, bezpieczeństwo i higiena pracy, zatrudnienie dzieci, ochrona pracy nieletnich (młodocianych pracowników), legalne zatrudnienie, brak przymusu pracy, ochrona środowiska oraz etyczne działanie w biznesie.

${ }^{20}$ G. Miller, D. Kędzierska, K. Ordyńska, A. Abec-Domańska, R. Sroka, Standardy etyczne i socjalne przepustkq dla małych i średnich przedsiębiorstw do współpracy z dużymi klientami, Ministerstwo Inwestycji i Rozwoju, Warszawa 2018, ss. 7-8. 
Audyty mogą przeprowadzać tylko jednostki posiadające odpowiednie uprawnienia i zatwierdzone przez amforiBSCI, w tym imiennie zatwierdzeni audytorzy posiadający kwalifikacje potwierdzone przez amfori. W przypadku amforiBSCI należy brać pod uwagę, że audyt musi zostać potwierdzony bezpośrednio przez firmę, która jest jednocześnie uczestnikiem amforiBSCI ${ }^{21}$.

Najstarszą inicjatywą samoregulacyjną dedykowaną standardom etycznym w łańcuchu dostaw jest Social Accountability International. Organizacja ta opracowała normę Social Accountability 8000 (SA8000). Celem normy jest zapewnienie ochrony osobom zatrudnionym zarówno bezpośrednio przez firmę, jak i przez jej podwykonawców. Norma ta wymaga m.in. wdrożenia kompleksowego systemu zarządzania, nadzoru nad dostawcami i podwykonawcami, wdrożenia systemu zgłaszania naruszeń i efektywnej komunikacji z interesariuszami wewnętrznymi i zewnętrznymi. SA8000 pozwala na analizę najważniejszych rodzajów ryzyka w dziewięciu obszarach związanych z zarządzaniem miejscem pracy i łańcuchem dostaw, do których należą: praca dzieci, praca przymusowa, BHP, prawo do stowarzyszania się i do rokowań zbiorowych, dyskryminacja, praktyki dyscyplinujące, godziny pracy, wynagrodzenia, systemy zarządzania. Audyt SA8000 jest zawsze audytem trzeciej strony, co znaczy, że organizacja może ubiegać się o certyfikację niezależnie od relacji ze swoimi kontrahentami. Pomyślnie zakończony audyt SA8000, w przeciwieństwie do innych standardów, umożliwia otrzymanie specjalnego certyfikatu ${ }^{22}$. Spośród blisko 10000 firm, które przeszły pomyślnie audyt, blisko 17\% były to podmioty znajdujące się w Chinach ${ }^{23}$.

Inne popularne standardy oraz kodeksy etyczne i socjalne, których zakres i zasady funkcjonowania są zbliżone do jednego z przedstawionych powyżej modeli to: ICS - Initiative Clause Sociale, ICTI - International Council of Toy Industries, FLA - Fair Labor Association Accredited Monitor, RJC Accredited by the Responsible Jewelry Council (RJC) for conformity assessments for member certifications, RBA - Responsible Business Alliance, JAC - Joint Audit Cooperation.

Wydaje się, że tylko tych kilka wyżej scharakteryzowanych inicjatyw samoregulacyjnych w zakresie etyki biznesu stosowanych przez zachodnie koncerny u chińskich dostawców i podwykonawców wpływa na poprawienie

21 Ibidem, ss. 8-9.

22 Ibidem.

23 SA8000 Certified Organisations, źródło: http://www.saasaccreditation.org/?q= node/23, dostęp: 12.11.2018. 
standardów etyki biznesu w Chinach. Podstawą do takiego stwierdzenia może być chociażby liczba prowadzonych audytów zgodności z tymi standardami. Co ważne, ich zakres odpowiada na najważniejsze zidentyfikowane problemy w zakresie standardów pracy i przestrzegania praw człowieka. Natomiast odpowiedź na pytanie, czy samoregulacja jest skuteczna, czyli przyczynia się np. do zmniejszenia liczby przypadków łamania praw pracowniczych, nie jest jednoznaczna. Nie ma dostępnych całościowych danych porównawczych. Opisywane są natomiast konkretne przypadki firm, które zmieniły swój sposób zarządzania na zapewniający przestrzeganie praw pracowniczych, ochronę środowiska czy transparentny tryb podejmowania decyzji biznesowych.

Niemniej jednak prawa człowieka i prawa pracownicze w wielu miejscach wciąż są łamane pomimo stosowania przez same firmy zlecające produkcję kodeksów etyki zastrzegających konieczność przestrzegania praw pracowników przez chińskich dostawców. Mechanizm tego typu działań pozorowanych na przykładzie firm zabawkarskich opisany w magazynie „Forbes” wygląda następująco: „Firmy zabawkarskie używają swoich relacji z dostawcami także do unikania odpowiedzialności za złe warunki pracy lub łamanie prawa w miejscach pracy. W sytuacji, gdy opinia publiczna dowiaduje się o naruszeniu praw pracowniczych w łańcuchu dostaw jednej z korporacji, obwinia ona właścicieli fabryk lub innych klientów korzystających z usług tego samego dostawcy. Jeżeli presja opinii publicznej nasila się, korporacje twierdzą, że właściciele zakładów produkcyjnych nie stosowali się do przyjętego w firmie kodeksu postępowania i w związku z tym rozwiązują umowę z danym ośrodkiem produkcyjnym. W ten sposób producent zabawek publicznie staje w obronie praw pracowniczych, minimalizując własne ryzyko i potencjalne straty dla firmy. Zamiast przyjmować na siebie odpowiedzialność w sytuacji ujawnienia naruszeń praw pracowniczych, firmy używają technik minimalizowania strat i działania na zwłokę"24.

\section{Podsumowanie}

Powyższe rozważania pozwalają dostrzec, że same inicjatywy samoregulacyjne w zakresie etyki biznesu zachodnich firm wyznaczające standardy etyczne pracy i wpływające na przestrzeganie tych standardów w chińskich fabrykach nie wystarczą. Formalne rządowe i lokalne regulacje

${ }^{24}$ M. Krukowska, op. cit. 
wprowadzające nowe obostrzenia w zakresie ochrony praw pracowników i środowiska naturalnego również okazują się niedostateczne. Pogłębienie tego tematy wymagałaby oddzielnej analizy.

Można postawić tezę, że najsłabszym adwokatem przestrzegania praw pracowniczych w Chinach są sami pracownicy i reprezentujący je organizacje związkowe, które często odgrywają jedynie rolę fasadową. Aby wzmocnić pozycję organizacji związkowych w Chinach nie wystarczą odpowiednie regulacje prawne czy wymagania klientów, czyli zachodnich korporacji. Potrzebna jest zmiana na poziomie etycznym.

Opisywane w niniejszym artykule inicjatywy samoregulacyjne w zakresie etyki biznesu są niczym innym jak bezpośrednią próbą przeniesienia zachodniej etyki biznesu bazującej na prawach człowieka do odmiennych kulturowo Chin. Powstaje zatem drugie pytanie, czy podobny mechanizm mógłby zadziałać na głębszym poziomie: nie wdrażania technicznych zaleceń samoregulacji biznesowej, lecz np. realizacji zasady pomocniczości kształtującej warunki współżycia społecznego. Na to pytanie odpowiedzi nie jesteśmy w stanie udzielić, lecz z pewnością wymagałoby to zgody na większą autonomię grup reprezentujących pracowników. Można jedynie przypuszczać, że większa autonomia grup pracowniczych mogłaby wyzwolić ducha sprawstwa w staraniach o przestrzeganie praw pracowników nie tylko przez lokalne zarządy firm, ale również dzięki warunkom współpracy dyktowanym przez zachodnich zleceniodawców.

\section{Bibliografia}

Budner W., Tendencje rozwoju rynku nowoczesnych usług biznesowych w Polsce, „Acta Sci. Polonorum. Administratio Locorum” 16(1)/2017.

Cao L., A Study on Self-Regulatory Initiatives in China's Internet industry, Media@lse, London School of Economic and Political Science, London 2007.

Christmann P., Taylor G., Firm Self-Regulation Through International Certifiable Standards: Determinations, of Symbolic Versus Substantive Implementation, Paper submitted to the First Annual Conference on Institutional Mechanisms for Industry Self-Regulation Dartmouth University, Hanover, NH 2014.

Christmann P., Taylor G., Globalization and the Environment: Determinants of Firm SelfRegulation in China, „Journal of International Business Studies” (32)/2001.

Hensel P., Ponadnarodowi normodawcy i biznes, w: B. Glinka, M. Kostera (red.), Nowe kierunki w organizacji i zarzq̨dzaniu. Organizacje, konteksty, procesy zarzq̨dzania, Oficyna a Wolters Kluwer business, Warszawa 2012.

Krukowska M., Nieludzkie oblicze zabawek, „Forbes” 2.12.2014, https://www.forbes.pl/ csr/lamanie-praw-czlowieka-przez-przemysl-zabawkarski/fct40s8, dostęp: 12.11.2018. 
Malik R., Lokalizacja w offshoringu usług, CeDeWu, Warszawa 2016.

Matejun M., Outsourcing, w: K. Szymańska (red.), Kompendium metod i technik zarzq̨dzania. Teoria i ćwiczenia, Oficyna a Wolters Kluwer business, Warszawa 2015.

Meredith R., Chiny i Indie - supermocarstwa XXI wieku, Media Lazar, Warszawa 2009.

Miller G., Kędzierska D., Ordyńska K., Abec-Domańska A., Sroka R., Standardy etyczne i socjalne przepustkq dla małych i średnich przedsiębiorstw do współpracy z dużymi klientami, Ministerstwo Inwestycji i Rozwoju, Warszawa 2018.

Mokrysz-Olszyńska A., Rola kodeksów dobrych praktyk w ochronie konsumenta, w: C. Banasiński (red.), Ochrona konkurencji i konsumentów w Polsce i Unii Europejskiej (studia prawno-ekonomiczne), Urząd Ochrony Konkurencji i Konsumentów, Warszawa 2005.

Senden L., Soft Law in European Community Law, Hart Publishing, Oxford-Portland 2004.

Trocki M., Outsourcing, PWE, Warszawa 2001.

Yeung G., Mok V., What are the Impacts of Implementing ISOs on the Competitiveness of Manufacturing Industry in China?, „Journal of World Business” 40(2)/2005.

\section{Raporty}

2016 A.T. Kearney Global Services Location Index ${ }^{\mathrm{TM}}$ Top 20, www.atkearney.com/strategicit/global-services-location-index, dostęp: 15.10.2018.

An Investigative Report on HEG Technology: A Samsung and Xiaomi Supplier Factory, China Labor Watch, New York 2018.

China's service outsourcing grows in 2015, http://www.chinadaily.com.cn/business/chinadata/2016-01/20/content_23167866.htm

SA8000 Certified Organisations, źródło: http://www.saasaccreditation.org/?q=node/23, dostęp: 9.11.2018. 